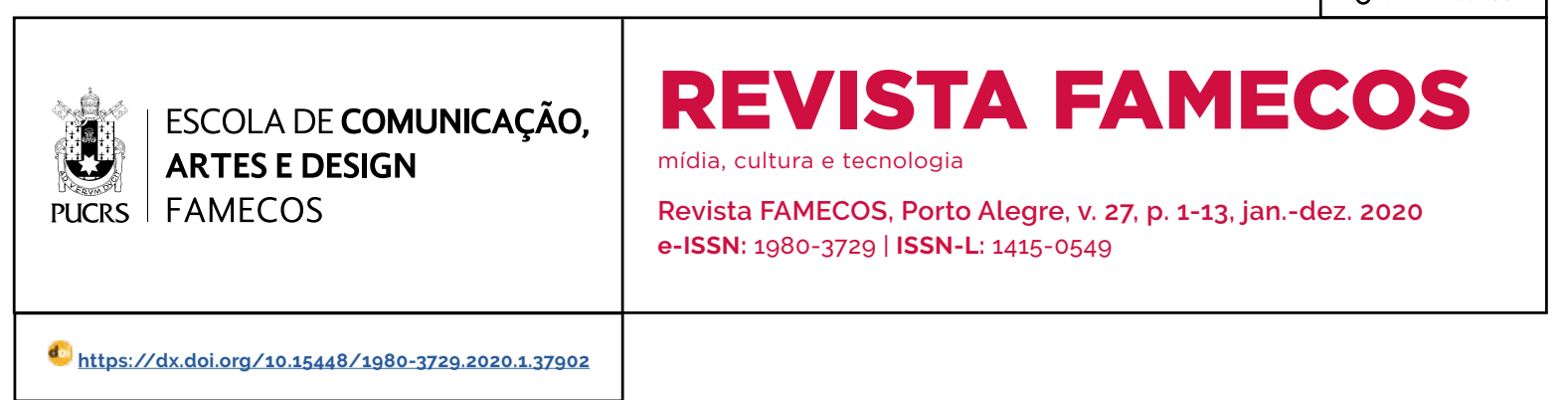

AUDIOVISUAL

\title{
O $\Phi$ da fotografia (lado b)
}

The photography's $\Phi$ (b-side)

El $\Phi$ de la fotografia (lado b)

\author{
Mauricio Lissovsky ${ }^{1}$ \\ 0000-0002-0734-790X \\ m@lissovsky.com
}

Recebido em: 30/4/2020.

Aprovado em: 14/6/2020.

Publicado em: 22/12/2020.
Resumo: Em 1979, diante da fotografia da mãe falecida, Roland Barthes escreveu os 48 pequenos capítulos de A Câmara Clara. Publicado em 1980, jamais deixou de ser debatido, admirado, criticado. Esse debate, no entanto, raramente serviu para alargar seu alcance ou aprofundar seus insights. Reduzido a um pequeno número de citações, a multidimensionalidade do texto se perdeu. Esse artigo é a segunda parte de uma releitura do ensaio onde os conceitos são pensados como episódios e a exegese subordina-se às tramas da narrativa. Os aspectos priorizados nesse Lado-B de phi (Ф) são: puncta, a palinódia, interfuit, eidos e aoristo. Palavras-chave: Roland Barthes. Fotografia. Câmara Clara.

Abstract: In 1979, looking at the portrait of his deceased mother, Roland Barthes wrote the 48 short chapters of Camera Lucida. Published in 1980, it never stopped being discussed, admired, criticized. This debate, however, has rarely helped to broaden its meaning or deepen its insights. Reduced to a small number of quotations, the multidimensionality of the text has been largely lost. This paper is the second part of a re-reading of the essay where the concepts are thought of as episodes and their exegesis is subordinated to the plot of the narrative. In the B-side of phi $(\Phi)$, we are going to visit the puncta, palinode, Schumann, interfuit, eidos and aorist.

Keywords: Photography. Roland Barthes. Camera Lucida.

Resumen: En 1979, mirando el retrato de su madre fallecida, Roland Barthes escribió los 48 capítulos cortos de Camera Lucida. Publicado en 1980, nunca dejó de ser discutido, admirado, criticado. Sin embargo, este debate rara vez ha ayudado a ampliar su significado o profundizar sus ideas. Reducido a un pequeño número de citas, la multidimensionalidad del texto se ha perdido en gran medida. Este artículo es la segunda parte de una relectura del ensayo donde los conceptos se consideran como episodios y la exégesis se subordina a la trama de la narración. En el lado B de phi $(\Phi)$, vamos a visitar Puncta, Palinódia, Schumann, Interfuit, Eidos y Aoristo.

Palabras clave: Fotografia. Roland Barthes. Cámara Clara. 


\section{Introdução}

Em 2020, A Câmara Clara, de Roland Barthes completou 40 anos. ${ }^{2}$ Seguramente, o mais influente ensaio sobre fotografia publicado na segunda metade do século XX. E, também, desde suas primeiras notas, um projeto de monumento em memória da mãe do autor. Em 2019 ofereci, no Rio de Janeiro (RJ) e em Olinda (PE), seminários de releitura dessa obra, procurando reencontrar nela o vigor da escrita original, sepultada sob a montanha de referências repetitivas e banalizações conceituais. Estava menos interessado na exegese teórica que na própria trama do texto, na sua arquitetura, e no imaginário que mobilizava para nos fazer ver e pensar a fotografia na sua absoluta, radical e selvagem originalidade. Sistematizei as notas desse seminário em dois artigos sobre o Phi $(\Phi)$ da fotografia.

Essa letra grega, que em suas anotações Barthes utilizava para abreviar o que depois será designado como Fotografia (com inicial maiúscula) é a face espelhada de um objeto cuja apreensão sempre escapa, simultaneamente duplo e coimplicado. Máximo de corpo e de materialidade de um lado, e todo o patrimônio da cultura ocidental de outro. Em uma face, o inominável, o bruto, o significante puro; em outra, a convenção, a arte, a civilização. Em $\Phi$, lemos o sinal gráfico de todas as (falsas) oposições que a CC desdobra: vida/ morte; dentro/fora; passado/presente, mãe/filho. Tomando o phi como chave de leitura, redigi dois artigos, dedicados aos dois lados desse signo. No "Lado A" os temas foram a Igreja de Saint-Sulpice, a personagem Albertine (de Proust), o Corpo e o Trauma. Nesse "Lado B", visitaremos o Punctum, a Palinódia, o compositor Schumann, o verbo latino Intersum, a fenomenologia do Eidos e esse estranho tempo verbal do grego arcaico, o aoristo.

\section{Puncta}

A noção de Studium, que se contrapõe ao Punctum, é introduzida primeiro. Tem caráter cultural, é da ordem da intenção, do contrato entre criadores e consumidores. Depende da educação. (BARTHES, 1989, p. 45-48). O Punctum é algo que interfere, quebrando o ritmo desse investimento. Barthes fala em escansão, como no versejar poético, mas deve igualmente pensar no verso bíblico salmodiado ou nas primeiras notações do canto gregoriano, cujos ritmos e entoações são marcados por pontos, dos quais as gramáticas modernas herdaram seus sinais de pontuação. É como uma ferida, uma picada. A formulação oculta uma provocação evidente: punctum é tanto o "ponto", a marca, como o ponto de vista, o ponto de fuga; tanto o "orifício" ou mancha, o acaso que fere, como o diafragma que permite a passagem das imagens para o interior da câmera escura, o que faz conviver, no mesmo dispositivo, o racional e o irracional.

Ao enumerar os sentidos da palavra punctum, Barthes segue a sequência de significados propostas por um dicionário latim-francês popular em seu tempo de estudante. Mas depois de reproduzir as primeiras, salta algumas acepções correntes, inclusive "voto" e "ponto de equilibrio" (como em uma balança) e convoca a décima e última: "lance de dados"з. Curiosamente, deixa de mencionar puncutm temporis, o momento, o instante, que ainda sobrevive em português em expressões como a hora "em ponto". Não é uma acepção insignificante, pois é a mais rica em abonações do verbete, entre essas, uma retirada das Epistolas Morais de Sêneca: "Punctum est, quod vivimus, et adhunc puncto minus"4 (GAFFIOT, 1934, p. 1278). A morte esteve lá, inscrita na instantaneidade do punctum, ameaçando o narrador desde o primeiro momento, tocaiada na lingua morta em que Barthes foi buscá-lo.

O studium reconcilia a fotografia com a sociedade. Fornece álibis para o fotógrafo, justificativas que the autorizam a manipular algo tão perigoso. Esses álibis se confundem com as "funções" sociais da fotografia: "informar, representar, surpreender, dar significação, provocar

\footnotetext{
A Câmara Clara, CC nesse artigo, foi lançada em 25 jan. 1980. Cerca de um mês depois, seu autor seria atropelado e viria a falecer depois de uma longa agonia no hospital. Todas as indicações de página sem menção direta ou indireta a autor referem-se a essa obra.

3 "[...] punctum é também picada, pequeno orifício, pequena mancha, pequeno corte - e também lance de dados" (BARTHES, 1989, p. 47).

4 É num momento que vivemos, e até mais breve que um momento. (tradução nossa)
} 
desejo" (BARTHES, 1989, p. 48-49). Se um punctum é uma espécie de subversivo, de sabotador da mensagem fotográfica, o ensino de fotografia, tal como praticado nas escolas da publicidade, de jornalismo, ou de artes, teria por objetivo blindar a imagem contra a perturbação do punctum. 0 resultado dessa blindagem é uma "fotografia unária" (BARTHES, 1989, p. 64). O termo é tomado emprestado da gramática gerativa, formulada por Noam Chomsky na década de 1950. As transformações unárias são aquelas em que a unidade do sentido é preservada, preservando-se a informação. A fotografia unária seria aquela que "transforma" enfaticamente a realidade sem fazê-la "vacilar". Além do fotojornalismo e da publicidade, dos quais se exige unariedade para comunicar com eficiência suas mensagens: a fotografia pornográfica também seria unária - pois ela é como uma vitrine que exibe uma única joia (BARTHES, 1989, p. 65).

Entre as várias acepções de punctum, Barthes introduz uma que os antigos romanos desconheciam: "objeto parcial" (1989, p. 69). Especialmente difundido por Melanie Klein, o conceito psicanalítico remete a uma parte que se torna, parcialmente ou de modo intermediário, objeto da pulsão. Tanto vale para os fetichistas, para os cultuadores de partes do corpo, como para alguém, por exemplo, que deseja casar-se para ter filhos. Os objetos parciais por excelência são o seio e o pênis. Na clínica, a entrada na vida adulta corresponde à passagem de objetos parciais para objetos totais; mas alguns teóricos consideram que os sujeitos continuando fantasiando e fantasmando objetos parciais a vida toda. Por isso, Barthes nos diz, talvez brincando, que fornecer exemplos de puncta é "entregar-se" (1989, p. 67).

Em "O Terceiro Sentido", Barthes observara as "unhas compridas de Goering". Era, então, de um antepassado do punctum que se tratava, o "sentido obtuso" (1984, p. 53). Na CC, mencionam-se as unhas grandes nos retratos do século XIX e as unhas sujas de Tristan Tzara em uma foto de

Kertész. Talvez Barthes tivesse, de fato, um não sei quê por unhas grandes e sujas, em particular as masculinas. Na foto de Andy Warhol, por Duane Michals, "o punctum não é o gesto, é a matéria um tanto repelente das suas unhas espatuladas, simultaneamente moles e descarnadas" (BARTHES, 1989, p. 73). Entregou-se? Deixou escapar um fetiche singular? Ou brinca conosco, aludindo à conhecida provocação de Sócrates de que não há uma ideia para as unhas sujas? Uma vez que a sujeira debaixo das unhas não participa do mundo das essências, tendo sido banida do eidos platônico, o eidos fotográfico, restabeleceria sua cidadania, ainda que fugaz, na forma do punctum, do inominável. No Theatrum Philosophicum, de 1970, Foucault (1980, p. 40) já havia dado a senha:

\begin{abstract}
Converter o platonismo (trabalho responsável) é incliná-lo a ter mais piedade pelo real, pelo mundo e pelo tempo. Subverter o platonismo é tomá-lo desde o cume (distância vertical da ironia) e retomá-lo na sua origem. Perverter o platonismo é apurá-lo até ao último detalhe, é baixar (de acordo com a gravitação própria do humor) até a um cabelo, à sujeira debaixo de uma unha que não merecem a honra de uma ideia (tradução modificada).
\end{abstract}

Mas, ao remeter as unhas repelentes de Andy Warhol a Platão e Foucault, já as converti em studium. O punctum, enquanto tal, o tal do punctum, é apenas "uma fulguração" (BARTHES, 1989, p. 74) - expressão que parece ter saído do vocabulário benjaminiano, assim como "detonador" (BARTHES, 1989, p. 75) e "estrelinha na trama do texto" (BARTHES, 1989, p. 75). Não é algo necessariamente notado à primeira vista: é um satori (o termo japonês para a iluminação budista), a "passagem de um vazio". Se demorasse um pouco mais, deixaria de ser punctum, poderia ser analisado. Mas como resistir ao studium? Há o esparadrapo no dedo da garota, a gola Danton no menino (Figura 1). Barthes confessa: "Sou um selvagem, uma criança - ou um maníaco; ponho de lado todo o saber; toda a cultura, abstenho-me se ser herdeiro de um outro olhar" (BARTHES, 1989, p. 77). 
Figura 1 - Lewis Hine. Idiot Children in an Institution, New Jersey, 1924

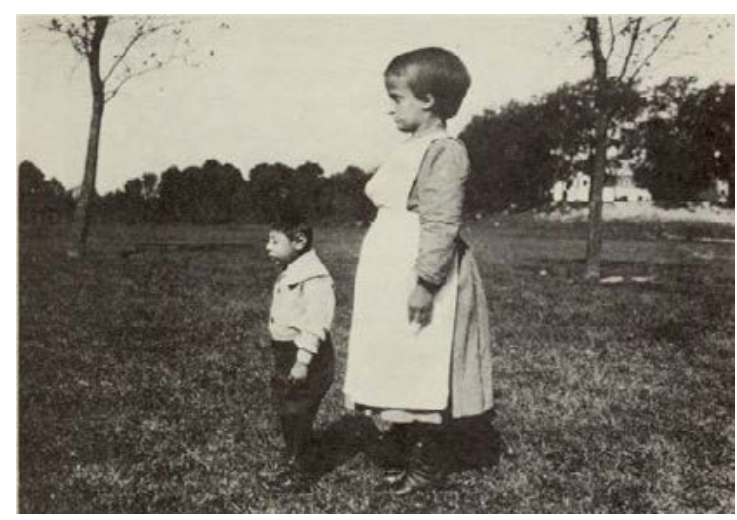

Fonte: BARTHES, 1989, p. 76

Não foram poucos os esforços que procuraram converter CC em método. Há dezenas de textos na Internet, em todas as línguas, que se propõem a aplicar studium e punctum a esse ou aquele corpus em particular. Raramente leio algo desse tipo que verdadeiramente me interesse. Tudo me parece uma certa dilaceração do corpo a serviço do corpus, porque, ao contrário do studium, o punctum não ensina nada. ${ }^{5}$ Mas pode interromper, sacudir e permitir uma revisão estudiosa dos materiais. ${ }^{6}$ Derrida insiste que, a despeito da irredutibilidade do punctum, ele é, desde o início, duplo, pois aponta simultaneamente para si próprio e para mim (2001, p. 39). Sugere que há 3 maneiras de caracterizar a relação entre punctum e studium: "suplementar" (é acrescentado, mas já estava lá); "ritmica" (pois a fotografia pretende sempre interiorizar, capturar, isso que escapa e que resiste à apropriação); e "assombração", isto é, nem a vida, nem a morte, mas, tomando do vocabulário de Levinas (2001), sem citá-lo, o "sombreamento" de uma pela outra" (DERRIDA, 2001, p. 41).

A distinção entre studium e punctum seria apenas um simulacro de distinção, cujo antagonismo se dissolve para "complicar e reformular não apenas a oposição entre singularidade e predicabilidade, contingência e repetição, detalhe e totalidade, mas também entre intencionalidade e não intencionalidade (CADAVA; CORTÉS-ROCCA, 2006, p. 13) No entanto, uma observação crucial é feia por Cadava e Cortés-Rocca (2006): Barthes identifica os puncta por meio de "associações e deslocamentos que evocam sua história, seus afetos, e sua inscrição na linguagem, na cultura, na rede familiar". "Se esse detalhe em particular the comove, se ele registra essa ferida em particular, é porque essa ferida já está nele, em algum lugar na sua história, ainda que deslocado, cifrado e de maneira ilegivel" (CADAVA; CORTÉS-ROCCA, 2006, p. 15).

Enquanto caça-punctum, Barthes - criança ou selvagem - não pode abrir mão da memória. A gola Danton - qual Danton? O guilhotinado? Um menino de cabeça tão pequena e gola tão grande. Não demora muito e vão cortá-la. Não devia haver criança francesa que não temesse por seu pescoço. E não adiantava explicar que a Revolução Francesa foi há muito tempo e ninguém vai decapitar o seu pintinho. A cabeça desse menino até encolheu de tanto "terror". Tudo isso, para mim, está na gola ou no nome da gola? O que seria dessa gola sem esse nome?

Derrida havia sugerido que a melhor maneira de pensar a relação entre as noções de studium e punctum seria a forma musical do "contraponto". Barthes chegou a anunciá-los como temas de uma sonata clássica, que como sabe bem, tem 3 movimentos, o terceiro representando a sintese dialética dos anteriores: studium, punctum e....

A palinódia, anunciada na final da primeira parte do livro, interrompe a sonata antes que o terceiro movimento seja introduzido. O contraponto, de fato, é tudo que lhe resta, como nas formas simétricas, espelhadas e retrógradas da Arte da Fuga, de Bach - a última obra de gênio do compositor, antes que seus filhos inventassem a sonata clássica.

\section{A Palinódia}

No último capítulo da primeira parte do livro, Barthes revisa seus passos e anuncia uma reviravolta (BARTHES, 1989, p. 87-88). Nos conta que veio "caminhando de foto em foto", ou seja,

\footnotetext{
5 Sobre a distinção entre Corpo e Corpus, em Barthes, ver "O Ф da fotografia (Lado A)".

- Para um exercício de uma apropriação do punctum, como estranhamento, interrupção, sintoma - aplicado à análise fílmica, a partir da noção barthesiana de fotograma, ver LISSOVSKY; BLANK, 2010.
} 
comentando esse ou aquele punctum, o livro seguira uma trajetória linear. Esse percurso será agora interrompido. Uma fotografia irá interpor-se, uma que não permite que a caminhada prossiga. As imagens que examinou até então eram "todas públicas". Ainda que os puncta surgissem no interior de uma relação privada e pessoal, as fotografias eram todas provenientes de revistas e livros. Mas os puncta assinalados por ele não eram generalizáveis, portanto seriam incapazes de falar em nome do eidos da Fotografia, pois refletiam o seu "desejo", que era um "mediador imperfeito". Ao orientar-se apenas pelas fotos de que gosta, segundo um projeto "hedonista", jamais poderia reconhecer o universal, que necessariamente deveria abranger as fotos de que não gosta.

As novas premissas da pesquisa são então anunciadas. Uma vez que seu objetivo é a redução eidética da fotografia, a essência buscada deve necessariamente servir a um sujeito qualquer diante de uma imagem qualquer. Sublinho aqui: qualquer/qualquer, e não todos/todas - pois são regimes distintos do universal. O universal que diz respeito a todas as fotografias para todas as pessoas é um universal do tipo categórico. Decorre de generalizações e suas categorias são tão mais adequadas quanto abarcam, submetem os casos sem deixar resto. Já o universal no regime qualquer/qualquer ou quaisquer/quaisquer está do lado da potência, disso que pode ou não pode ser. Assim, o universal todos/todas incluiria na categoria fotografia tudo que possui um conjunto determinado de características pertinentes e, preferencialmente, exclusivas da Fotografia. Já o universal qualquer/qualquer não tem um conjunto de atributos definido de antemão, mas dirá que é fotografia algo que possa sê-lo até onde (ou até quando) não possa mais.7

A segunda premissa adotada por Barthes decorre da primeira, pois se é da potência que se trata (dessa distinção que qualquer pessoa poderia fazer no campo das imagens para que uma e não outra pudesse ser uma fotografia), não é na variedade de imagens ou na variedade de sujeitos que essa essência deve ser buscada, mas, ao contrário mergulhando ainda mais fundo "dentro de mim próprio". Na última sentença do capítulo, Barthes dá um nome a sua reviravolta: palinódia (1989, p. 88). Ele tem suficiente controle sobre a escrita para saber que muitos leitores vão se deter diante uma palavra que estão lendo pela primeira vez. Alguns prosseguiriam, na expectativa de que as páginas seguintes esclarecessem seu significado. Outros iriam ao dicionário. Mesmo os que conhecem seu significado, são forçados a uma breve interrupção, um espanto: que diabos essa palavra, vinda dos confins da retórica e da poética clássica está fazendo aqui?

Sua inserção nesse ponto da narrativa tem todas as caracteristicas do corte que representamos graficamente pela letra grega $\Phi$. Não se trata apenas de uma separação entre duas partes, mas do limite entre duas áreas que devem ser rebatidas uma sobre outra. O que é palinódia, afinal? Uma figura da retórica em que o orador - ou o poeta - se desdiz, retira o que havia dito antes e passa a sustentar exatamente o oposto. A despeito de ter sido um recurso mais frequente na poesia e ainda hoje muito utilizado em certo tipo de argumentação jurídica, não é estranho ao ensaio e à filosofia. Um livro que se serviu da palinódia é a História da Sexualidade I, de Michel Foucault, onde a segunda parte, mais longa, desmente a primeira, em particular isso que o autor designa por "hipótese repressiva". Mas Foucault prenuncia sua reviravolta para o leitor atento, salpicando na primeira parte expressões como "parece que", "diz-se", ou abusando do futuro do pretérito e das formas condicionais (1982, p. 9-18). Barthes, no entanto, escondeu as pistas. Sua palinódia cinde em dois o livro e o leitor.

A segunda parte começa com a noite em novembro, "pouco depois da morte da minha mãe". A meu juizo, esse "encontro" só aconteceu, de fato, 7 meses depois, à tarde. Formulei a hipótese, no "Lado A" de $\Phi$, que aquilo que Barthes encontra em novembro/1977 é o número especial da Nouvelle Observateur que contém o texto de

7 Para uma discussão mais aprofundada dessa questão, que será retomada adiante nesse texto, ver AGAMBEN, 2007. 
Benjamin sobre o "futuro" inscrito no passado e o retrato do belo jovem Payne, condenado à morte. Por ocasião da palinódia, outro elemento é acrescentado a essa trama.

A última fotografia da primeira parte de CC é o autorretrato de Robert Mapplethorpe, com sua mão esticada no vazio, "no seu melhor grau de abertura, na sua densidade de abandono" kairos do desejo, escreve Barthes (1989, p. 87). Um convite ainda ou já uma despedida? Essa pergunta seria irrelevante, apenas retórica, pois bastaria repetir aqui que Barthes abandona seu desejo como critério para selecionar o corpus do livro com um gesto de adeus desse corpo

Figura 2 - Robert Mapplethorpe - Self Portrait, 1975

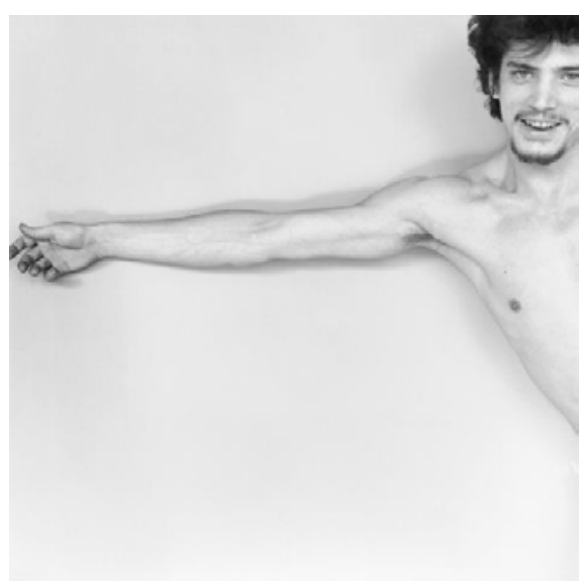

Fonte: National Galleries Scotland.

\section{Schumann}

A mãe já está morta, Barthes está vivo. A coleção de fotos na caixa de sapatos revela apenas fragmentos. Nenhuma lhe permite reconhecê-la por inteiro: às vezes, não é ela; às vezes é "quase" ela -; o "quase" ainda causa mais sofrimento. 0 "quase é o regime atroz do amor", o "estatuto decepcionante do sonho", onde ela nunca é completamente ela - como quando sonhamos com qualquer pessoa - a não ser, Barthes, que amável. Mas não existem respostas óbvias na CC. O autorretrato de Mapplethorpe foi publicado invertido, espelhado, desde a primeira edição - não tendo jamais sido corrigido. (Figuras 2 e 3) Talvez Barthes não tivesse consciência do engano, cuja origem não consegui determinar, mas qualquer aprendiz de studium fotográfico observaria que o Mapplethorpe original pode estar chegando ou convidando-nos com o braço direito, enquanto o da CC está indo embora, despedindo-se com o braço esquerdo. O espelhamento do retrato é uma premonição silenciosa do descarte do desejo e da palinódia que será anunciada logo a seguir.

Figura 3 - Reprodução invertida em A Câmara Clara.

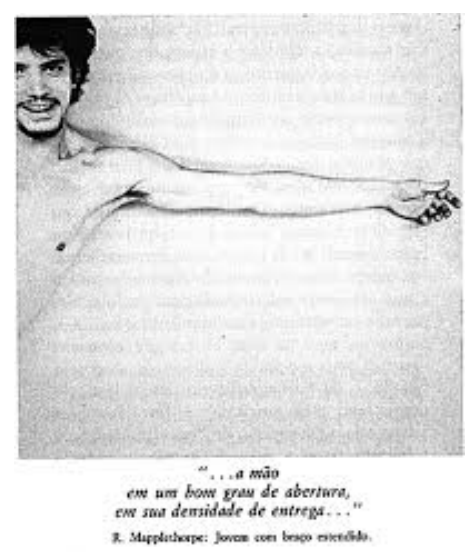

Fonte: BARTHES, 1989, p. 86.

nos diz que só sonha com ela (1989, p. 94-96). Finalmente, o encontro. Trata-se de uma mãe que ele nunca viu, aos 5 anos de idade. Essa fotografia não corresponde a nenhuma lembrança, mas suas qualidades atravessam o tempo. A menina não tem nada de "histérica", ela não "imita os adultos" (1989, p. 98) - essa maldição que paira sobre os retratos infantis mais antigos. A impossibilidade de uma pose que não é pose, finalmente a encontra nessa mãe-criança. 
Sabemos que jamais irá mostrá-la. Mas se permite duas comparações. Um retrato que Nadar faz de sua esposa Ernestine, que Barthes, mesmo informado a respeito, faz questão manter o leitor em dúvida, legendando, equivocamente "Nadar: mãe ou mulher do artista" (1989, p. 100) e uma peça da última obra de Schumann - as Canções da Aurora. ${ }^{8}$ Seu comentário a respeito do Canto n. 1, pode soar estranho - "harmoniza simultaneamente com o ser da minha mãe e com o desgosto que a sua morte me provoca" (1989, p. 101) -, mas devemos considerar que na CC a música está ligada ao luto e à relação entre amor e morte. Como a fotografia, a música sempre sinaliza uma partida de nós mesmos, nossa morte iminente. No entanto, apesar de parecer efêmera, à primeira vista, a música deixa um traço, um vestígio de si, que desde a antiguidade chamamos de "ritmo".

Emile Benveniste, por quem Barthes tinha grande admiração, lembra que a antiga noção grega de ritmo não era exclusiva da música, mas dizia respeito à forma, na medida em que assumida, pelo que é movente, fluido (1966, p. 333) Ainda hoje podemos falar do ritmo das ondas e isso não remete exclusivamente ao intervalo temporal entre uma e outra, mas também à sua curvatura, ao contraste entre cristas e vales. A música também imprime suas formas no mundo e Cadava e Cortés-Rocca (2006) sustentam que, para Barthes, ela não é diferente do corpo que ama:

\begin{abstract}
uma vez que ambos entram em seu próprio corpo e ao entrar, impedem-no de permanecer apenas 'ele', mesmo se, como sugere, 'ele' e seu corpo se tornam um tipo de "órgão musical" que toca 'essa' música de um outro como se estivesse emergindo dele (como o punctum a música é acrescentada ao seu corpo, mesmo que já estivesse lá) (2006, p. 31).
\end{abstract}

Ao explicar por que gostava mais de tocar Schumann que escutá-lo em discos, Barthes (1984) escreve:
É que a música de Schumann vai mais longe do que os ouvidos; ela corre no corpo, nos músculos, pelo bater do ritmo, e nas visceras, pela voluptuosidade do melo: dir-se-ia que de cada vez a peça só foi escrita para uma pessoa, aquela que a toca: o verdadeiro pianista schumanniano sou eu (1984, p. 238).

Por isso, Cadava e Cortés-Rocca (2006) podem concluir que a música, tal como o fotografado, é da ordem do acontecimento: "aparece apenas para desaparecer, e por isso requer, a todo momento, um trabalho de luto" (2006, p. 33).

Os gregos "entravam na morte" de costas, diz Barthes, porque o que tinham "diante deles era o seu passado" (1989, p. 102). Ele também seguiu um percurso retrógrado até alcançar a mãe-criança. Mas esse recuo é ainda uma atualização do fim da vida da mãe, quando Barthes cuidava dela como se fosse sua filha (1989, p. 103). "Redução eidética": de todas as fotos para apenas uma foto; de toda a sua biografia até muito antes de seu nascimento, a remota fotografia de sua mãe criança. A "essência da fotografia" poderia provir dessa foto particular. Ela estava no centro do labirinto formado por todas as fotos do mundo (1989, p. 104).

Todas? Não, de modo algum. Não se trata de uma foto-sintese, o terceiro movimento da sonata. É uma foto qual-quer. O ponto de vista do desejo e do prazer, que guiou a formação do corpus iconográfico do livro foi substituido pelo ponto de vista do amor e da morte. Decide não a mostrar ao leitor porque seria uma "das mil manifestações do 'qualquer'", que só poderia interessar a ele como studium, pois não haveria nela uma "ferida" que lhe atingisse (1989, p. 105). O leitor talvez aceite essa extrema demonstração de recato, sem se dar conta que o retrato materno deve ser mantido oculto exatamente para que seja uma foto qualquer. Pois essa imagem, sendo foto qualquer, não o é, indiferentemente. Pelo contrário, como ensina Agamben, é uma imagem qualquer aquela que "seja como for não é indiferente" (AGAMBEN, 2007, p.11). No qual-quer, ecoa o querer, o amar.

\footnotetext{
8 Barthes era schumanniano, como se diz dos aficionados desse compositor, assim como Felix Guatarri, que também tocava piano. Há dois aspectos curiosos nessa referência. As Canções da Aurora, op. 133, foram compostas em 1852. Alguns dias depois de conclui-las, Schumann tenta suicidar-se. Mesmo falhando, não compõe mais nada nos anos seguintes. As composições de Schumann posteriores a 1850 são pouco tocadas, pois, para alguns, essas obras não teriam mais a mesma qualidade em virtude do crescente desequilibrio do compositor. Mas, para outros, a despeito de compor com mais dificuldade, seriam complexas e geniais.
} 
Quod-libet: o que quiser, conforme lhe apraz. Quod-libet, em música, desde os tempos da Renascença, uma combinação de melodias em contraponto. Viver no amor, observam Cadava e Cortés-Rocca, é viver em contraponto, "no limiar entre a vida e a morte" (2006, p. 24).

\section{Interfuit}

A generalização a partir da fotografia do Jardim de Inverno é possivel porque Barthes pode ler sua própria morte, não somente em relação à morte da mãe, mas em relação à morte anunciada por qualquer fotografia. Mas, na medida em que, sendo fotografia, essa morte já ocorreu e ainda vai ocorrer, o contraponto fotográfico está em jogo, um canto a duas vozes: a voz da banalidade (a voz de toda fotografia, aquilo que todo mundo vê e sabe) e a voz da singularidade (também banal, mas a voz de uma emoção que é só dele) (BARTHES, 1989, p. 108). Esse canto a duas vozes da fotografia, o canto de duas banalidades, é a inegável convivência entre a realidade e o passado - "inegável", porque uma vez negada, deixa de ser a banalidade de uma fotografia "qualquer". Essa dupla remissão é a peculiaridade do referenciamento fotográfico, seu noema, isto é, seu sentido.

O que Barthes nos diz é que "o nome do noema da Fotografia" é "Isto Foi", ou "o Inacessivel". Ele experimenta ainda uma palavra latina: interfuit (a $3{ }^{\text {a }}$ pessoa, no passado, do verbo intersum), que quer dizer algo como "estar entre", "ficar apartado" e, principalmente, "estar separado por um intervalo". Esse é o sentido mais comum do verbo, que não prevaleceu em português como em outras línguas modernas, herdeiras do sentido mais culto e poético, de importar-se, interessar-se, concernir-se. Assim como havia buscado no latim o par punctum/studium, fazendo rebater o arcaico sobre o moderno, o interfuit é esse objeto lançado no meio, interposto, a linha que corta o $\Phi$, que separa vida e morte, reduzida pela fotografia a um "simples disparo, aquele que separa a pose inicial do papel final" (1989, p. 130). Talvez possamos escutar na superficie fotográfica que se interpõe entre o presente e o passado, um verbo que não existe em português: entresser, que se diria, tendo havido algo cuja existência foi abruptamente interrompida no passado, que entrefoi. ${ }^{9}$

Por que esse noema não foi notado nas demais fotografias da caixa de sapatos se diz respeito a todas delas? Exatamente porque elas não o vocalizam como unanimidade, não é entoado em unissono por todas as vozes, pois se trata, em cada uma delas, de seu singularíssimo "isto". Mas também não esteve oculto. É tão banal que teria passado despercebido em meio a tantos interesses do Studium e aos eventuais prazeres ou repulsas que suscitavam. O sentido de cada uma dessas imagens foi "vivido com indiferença, como coisa evidente". Foi dessa indiferença que a foto do jardim de inverno o "despertou". Um "despertar brusco, fora da 'semelhança'" (BARTHES, 1989, p. 150). Não se trata de uma foto em que a mãe está mais parecida do que nunca com ela mesma, mas uma foto que rompe com todo investimento analógico. Por mais espantoso que seja, desse encontro singular e pessoalíssimo nasce o "nome do noema", sua representação no campo da linguagem, pois como tal, é inominável, irrepresentável, intratável: "Isto foi" (BARTHES, 1989, p. 158). Agora o verdadeiro luto será feito, um livro será escrito (ou acabou de sê-lo), Henriette terá um monumento enquanto perdurar a celebridade de seu filho - e ela já dura 40 anos.

\section{Eidos}

A CC é uma investigação fenomenológica isso Barthes nos informa de imediato. Mas seus primeiros esforços, orientados pelo desejo, não the permitem o passo decisivo. Aposta primeiro na dualidade punctum/studium que resulta em uma concepção contrapontística da fotografia. Suficiente para dar conta de sua infinita variedade, mas não alcança ainda o eidos, pois seguindo a proposta do criador da fenomenologia, Husserl, 
dois passos são necessários para realizar a redução: primeiro, abrir mão das teorias e concentrar-se nas próprias coisas; e segundo, abrir mão das coisas e observar apenas as essências. Mais, precisamente, as essências como sentido dos fenômenos (isso será chamado redução eidética).

O tipo de universalidade que decorre dessa operação não é empírica como, por exemplo, asseverar que toda fotografia é resultado da luz refletida por objetos sobre uma superficie sensivel. Nos termos de Husserl, trata-se de uma "universalidade do conhecimento das essências" e, ao dizê-lo desse modo desde já nos damos conta que não pode ser formulada na ausência de um sujeito. Isto é, a redução fenomenológica não faz a descrição exaustiva e acurada do que vejo em determinado objeto, mas procura dar conta do meu ver desse objeto (HUSSERL, 1990).

O sentido subjetivo de qualquer fotografia é "isto foi", pois, a redução fenomenológica não dá conta do que vemos em cada uma delas, nem do que vemos em todas elas, mas de como vemos quaisquer delas. Enuncio "quaisquer" em vez de "todas" - forçando aqui uma distinção que não está presente na fenomenologia husserliana -, para não me desvencilhar do sujeito, pois sem sujeito não há qualquer. Na conversão de todos em qualquer, cada qual se vê orientado a um sujeito que o quer.

O esforço shumanniano, sob o risco da loucura, de harmonizar amor e morte, deve ceder passo à implicação do sujeito na redução que acaba de ser realizada. Barthes retorna ao tema da pose, que esteve presente na primeira parte do livro como cena, teatralização, constrangimento. Agora nos diz que a pose não é parte da técnica do fotógrafo, nem uma atitude do modelo, mas da inclusão do olhar do espectador ao contemplar uma foto: "Faço recair a imobilidade presente no 'disparo passado', e é essa paragem que constitui a pose" (BARTHES, 1989, p. 111). Por isso, a fotografia, tal como a história, não se constitui sem que alguém a olhe. Ela é "histérica".10

A "paragem", a "pose", é decisiva pois ela marca a diferença entre fotografía e cinema. Por isso Deleuze não tomará a distância em relação ao "real passado" como constitutiva do cinema, mas sua simultaneidade em relação à consciência (1985, p. 32), resgatando a diferença ontológica postulada por Bazin: a fotografia como molde, o cinema como modulação (BAZIN, 1991). Na fotografia, sustenta Barthes, o peso do Real seria muito mais forte. Enquanto no cinema, um fotograma conduz a outro, a fotografia é "sem futuro", e isso seria seu "patético, sua melancolia". Valendo-se de termos retirados da concepção do instante a fenomenologia dirá que o cinema é protensivo (ele se inclina, se volta para o que vem), já a fotografia "reflui da apresentação para a retenção"). O cinema seria apenas "'normal', como a vida" (BARTHES, 1989, p. 126).

William Casby posa para a câmera de Richard Avedon. A legenda informa: "nascido escravo". Barthes, comenta: "O noema aqui é intenso, porque aquele que eu vejo ali foi escravo" (1989, p. 113). Em 1988, publiquei um livro com uma série inédita de retratos de escravos, em formato carte de visite, feitos pelo fotógrafo português Christiano Junior, em torno de 1865 (AZEVEDO; LISSOVSKY, 1988) Eram quase todas inéditas - e seu autor, por ocasião da pesquisa, um fotógrafo inteiramente desconhecido, pois viveu poucos anos no Brasil. Além da extensão dessa série, única no gênero, as fotografias não correspondiam à imagem dos escravizados que se via nos livros escolares (o trabalhador do eito, a mucama, a ama com bebê). A despeito dessas fotografias serem raríssimas, não apenas em virtude de sua antiguidade e de seu tema, mas também porque Christiano Junior fez poucas cópias e comercializou menos ainda, elas se tornaram, no século XXI, a ilustração canônica da escravidão urbana brasileira. No ano passado, uma das imagens dessa série, particularmente significativa, apareceu em um leilão na Internet (Figura 4). Não havia identificação de autoria ou data, mas certamente outra pessoa, além de mim, a reconheceu. $\mathrm{O}$ leilão ocorreu em 10 de maio de

10 "A História é histérica: só se constitui se a olharmos e, para a olharmos, temos de nos excluir dela" (BARTHES, 1989, p. 93-94). 
2019. Os lances pela internet começaram em R\$ 100 e foi afinal vendida por R\$1.004,00. Tivesse sido creditada e datada pela leiloeira, certamente teria alcançado um valor superior. Há 30 anos, quando publiquei o livro, esses retratos não tinham qualquer valor. Estavam esquecidos no fundo de uma gaveta do arquivo da Secretaria do Patrimônio Histórico e Artístico Nacional (SPHAN). Há 180 anos, talvez, os dois escravos que vemos cumprimentando-se no carte de visite como dois príncipes africanos também foram leiloados no porto do Rio de Janeiro. Se fossem jovens e fortes, talvez tivessem saído por um conto e meio de réis cada. O meu livro, por sua vez, em valores de hoje, foi vendido no lançamento por cerca de 60 reais. Recentemente um exemplar esteve à disposição dos interessados na Livraria Gato do Sebo, na Estante Virtual, por R\$ 800.

Figura 4 - Christiano Júnior. Escravos de Ganho. Rio de Janeiro, c. 1865

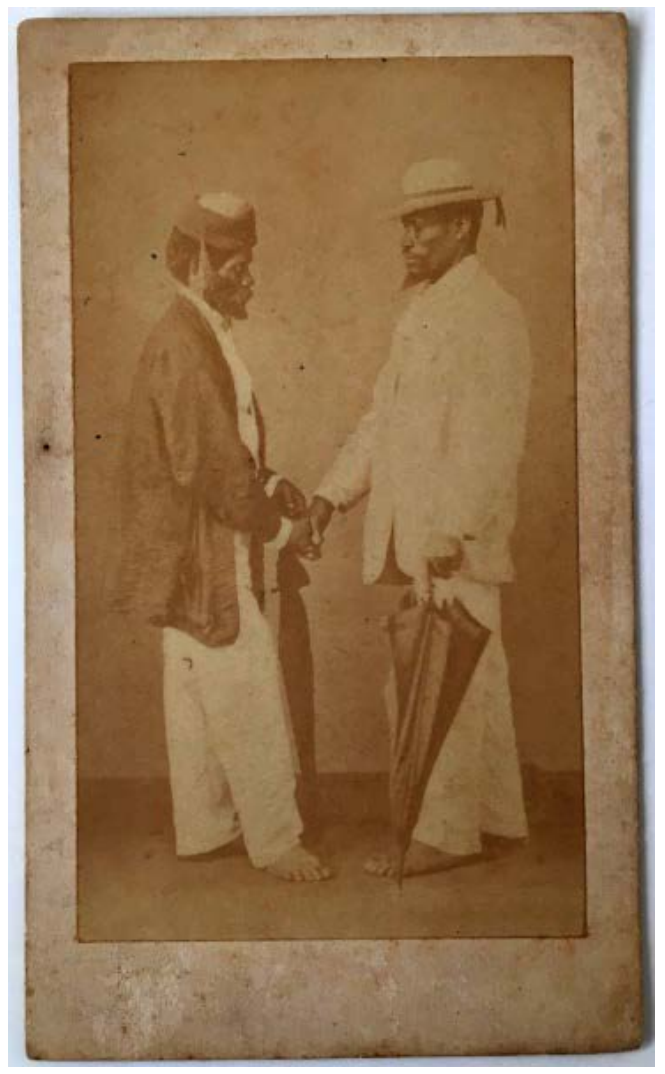

Fonte: AZEVEDO; LISSOVSKY, 1988, p. 57.
Isto foi, isto é, isto ainda será. Quanto tempo vai levar para que um dos raros cartes de visite colecionáveis de Christiano Junior, que agora vale mais que meu livro, igualmente raro, supere o valor pelos quais foram vendidos esses braços escravizados que carregam guarda-chuvas e tecem cestos? E algum de seus descendentes, mais por necessidade que vaidade, nos dias hoje, ainda posaria pelo mesmo vintém que Christiano pagou pela aparência de seus antepassados?

Barthes sustenta que "a data faz parte da foto... porque ela faz erguer a cabeça, faz o cômputo da vida, da morte, a inexorável extinção das gerações" (1989, p. 119). 1865, o retrato; 2019, o leilão do retrato. Ergo a cabeça: 1988, meu livro, e todos os leilões pregressos e futuros. O noema é isso. Não é o fim da história ou o fim da pesquisa. Mas seu ponto de partida, seu núcleo dramático. A História, por sua vez, é essa série mais ou menos infame de reprises e de repetições. Na pesquisa, na História, toda a fotografia me diz respeito, "pois sou o ponto de referência de toda a fotografia e nisso reside o meu espanto, ao pôr-me a questão fundamental: por que razão vivo aqui e agora?" (1989, p. 119).

\section{Considerações Finais - Aoristo}

A linguagem não pode certificar ou autenticar nada, a não ser por meio de dispositivos como a lógica ou o juramento. A linguagem seria, por sua natureza, ficcional. Já a fotografia teria de esforçar-se, montar e convocar truques para fabular. Valendo-se de uma ideia que também serviu a Benjamin, Barthes sustenta que a fotografia é uma "profecia ao contrário", "uma Cassandra com os olhos fixos no passado" (1989, p. 121). E conclui: a fotografia está obrigada a dizer a verdade, ela pode mentir ou ser "tendenciosa" sobre o sentido da coisa, mas não sobre sua "existência" (1989, p. 122). Se pode ser uma cena, então participa do "teatro desnaturado da morte", do "teatro morto da morte" (1989, p. 127). É teatro sem catarse, isto é, sem um final que recompense o espectador, seja por meio da vingança ou da promessa de felicidade. ${ }^{11}$

\footnotetext{
11 Por sua relação com "quadro vivos", meio vivos/meio mortos, meio gente/meio manequim, as fotografias de Bernard Faucon impressionavam tanto a Roland Barthes (2005a, p. 213-218).
} 
Ao relacionar a fotografia ao quadro vivo, Barthes arrisca uma especulação que pode ultrapassar o "isto foi" e sugerir um tempo próprio à fotografia. Para sublinhar seu aspecto arcaico, mitológico, argumenta que o tempo verbal da fotografia não é o passado perfeito (como o das recordações usuais), mas um tempo (ou um aspecto verbal) que não existe nas linguas modernas, o aoristo. Não se trata agora do latim, mas do grego. Os filólogos comentam que o aoristo é dificil de ser concebido por um falante moderno. Seria equivalente a uma combinação de gerúndio com particípio ("tendo derrubado o copo"; "tendo mergulhado na piscina"), ainda que os tradutores do grego costumem optar pelo pretérito perfeito ("derrubou o copo", "mergulhou na piscina"). No aoristo, algo ocorreu no passado, ocorreu de uma vez, foi antes de algo, ou logo após algo (isto é, pode ser incoativo, dando início a algo; ou cessativo, dando fim a algo). O que caracteriza o aoristo é que isso que ocorreu não tem qualquer duração implicada nele.

Aoristo significa, literalmente, "limitado". Parte da dificuldade aqui é que o passado perfeito moderno também não funciona igual no grego clássico, sugerindo, ao contrário, uma ação que tem alguma duração. Se digo "João acabou de comer e saiu", alguém pode entender que ele deu suas últimas garfadas, encerrou sua refeição, e foi embora. Mas tivesse usado o "aoristo" e dito "Tendo acabado de comer, João saiu", então compreende-se que saiu após terminar a refeição, sendo que "saiu" admite novamente uma duração, pois ele pode ter posto o casaco, aberto a porta etc., até finalmente sair.

Virando do avesso da fenomenologia barthesiana, concebi a "máquina de esperar" tomando como aspecto verbal da fotografia, o futuro do pretérito. Era o que me parecia mais fiel ao pensamento de Walter Benjamin, porque mostrava-se útil à montagem das imagens dialéticas, cujas composições nos abriam para os futuros irrealizados no passado. As fotografias não murmuravam para o historiador o que foi, mas o que "poderia ter sido" (LISSOVSKY, 2014, p. 33-43). Mas minha fenomenologia tomava por referência o fotógrafo (operator, nos termos da CC), enquanto a de Barthes, o espectator. O operator tem, a meu ver, uma espera plena de expectativas que serão necessariamente frustradas. O espectator, por sua vez, só pode esperar pela própria morte, que certamente virá. Barthes provavelmente diria que minha preferência pelo futuro do pretérito apenas dá ouvido a fantasmas, entrega-se à ilusão de que algo sobrevive à "morte crua" que a fotografia impõe: uma morte sem ritual, sem religião (1989, p. 130). Seu livro se chama A Câmara Clara porque o sujeito que a contempla, que investiga seu sentido, é sempre esse que vê a fotografia, jamais o que a realiza, que vive para e pela câmera escura. Por não ter nada por trás, por não ter profundidade, não ter uma verdade além das aparências (premissa que o Ocidente tanto valoriza), a fotografia se faz ainda mais "misteriosa e inacessivel" (147).

Mas do outro lado de $\Phi$, submetida ao Tempo soberano do "Isto Foi", há algo que atravessa essa "cortina de ferro". É o Olhar - esse olhar que a fotografia nos dirige é simultaneamente "efeito de verdade e efeito de loucura", pois a fotografia (o espectador da fotografia) confunde a realidade do "Isto Foi" com a verdade do "É Isto!" Uma "verdade louca" (1989, p. 157), uma nova forma de "alucinação": "falsa ao nível da percepção, verdadeira ao nível do tempo" (1989, p. 158). Será que o apelo do punctum, tomando a fotografia do jardim de inverno como paradigma, é a loucura, um mal de amor? Talvez seja a Piedade, sugere Barthes nas últimas páginas da CC, tal como a de Nietzsche que se lança "chorando ao pescoço de um cavalo martirizado" O filósofo enlouquecia de piedade; aquele que ia morrer abraçava o já morto (1989, p. 160). O punctum é esse mergulho na loucura, esse abraço de afogados. Lançamo-nos ao mar por piedade, e somos sugados juntos pelo redemoinho do Tempo.

Mais uma vez, no entanto, escapamos. Louca é a Fotografia, o $\Phi$ da fotografia, que dividiu a História, que coloca em contato, com um simples clique, a vida e a morte, que confunde realidade e verdade, que certifica o passado, desconfiando do presente. Para Barthes, a fotografia, longe de ser 
uma resposta iluminista a uma demanda racional é uma semente latente de loucura sempre pronta a explodir no rosto de quem a contempla (1989, p. 161). Essa loucura foi temperada, apaziguada pela sociedade de duas maneiras. A fotografia deve ser arte, mas só pode ser arte quando seu noema se torna inócuo, quando ele já não age sobre mim (1989, p. 161). Não surpreende, portanto, que tenha sido no campo da crítica de arte, na teorização da arte contemporânea, que a resistência às teses realistas de Barthes foi maior. o cinema, o cinema de ficção em particular, teria participado decisivamente dessa "domesticação da fotografia" (1989, p. 161). O segundo meio de a tornar séria, de controlar sua loucura, foi "generalizá-la, banalizá-la". Ela passa a dominar e a esmagar todas as outras formas de ser imagem. Sucumbem as gravuras, as pinturas figurativas etc. (1989, p. 162-163).

O "Isto foi" provém de um espanto próprio e intransferivel. O espanto inaugural diante da foto do irmão caçula do imperador, o espanto dos primeiros espectadores da fotografia, sobre o qual escreveu Pedro Miguel Frade (1992). Assim como Frade, Barthes reconhece que esse espanto estava em vias de desaparecer. Seu livro talvez fosse apenas um testemunho do Inatual, um vestígio arcaico de experiência destinada a esvair-se como o amor de seus pais, o amor entre ele e sua mãe. No capítulo 39, a torção especular do livro sobre si próprio torna-se clara. Existe um punctum além do pormenor: é o Tempo.

Ele agora pode contemplar a foto do rapaz condenado à morte que vira na Nouvelle Observateur logo após a morte da mãe. Agora que a foto do jardim de Inverno é a guardiã do noema, a mediadora universal de qualquer fotografia, pode olhar para essa foto e dizer que sua beleza é studium - toda a beleza, mesmo a beleza do jovem condenado (1989, p. 133). É da ordem do seu desejo e da cultura isso que the afetara. Ele já morreu e ainda vai morrer. Mas Barthes sabe que sua mãe menina morreu de fato. Ele testemunhou, estava a seu lado, sepultou-a. Mas Thomas Powell, o belo prisioneiro, não vai morrer porque todo mundo morre. Morre porque foi condenado à morte e será executado no dia seguinte. Barthes sabe disso porque leu a legenda da foto e talvez conheça algo de história norte-americana. No momento em que foi fotografada, no jardim de inverno, a mãe não sabe que vai morrer; ou se sabe, não imagina quando, e se imagina, nem passa agora por sua cabeça de criança. O jovem Powell, por outro lado, sabe que morrerá. Sabe que vieram lhe fazer a última foto, mas ao contrário da última refeição, jamais desfrutará dela. Thomas Powell, enquanto posa, não tem como evitar a consciência de que vai morrer amanhã. E Barthes sabe que ele sabe.

Ele vai morrer/ela vai morrer. Ambas as mortes estão inscritas na fotografia, mas todo um mundo as separa. No retrato de Powell, o studium só faz amplificar e multiplicar o punctum: o condenado sabe, Barthes sabe, o fotógrafo sabe e agora todos nós sabemos não apenas que Powell morreu, mas que a mãe de Barthes também, e que o próprio Barthes morreu logo após lançar esse livro, ainda que não fora condenado a isso por um juiz. E, claro, nós também vamos morrer, de um modo ou de outro, se não amanhã, algum dia.

Se Barthes tivesse vivido até recentemente (o que seria bastante improvável, uma vez que ele pertence a uma geração dizimada, nos anos subsequentes, pela epidemia de AIDS), o que diria da enxurrada de selfies postados a todo momento nas redes sociais? Provavelmente que pretendemos nos iludir, como Aquiles, que deseja ultrapassar a tartaruga percorrendo distâncias cada vez menores, até perder-se em infinitos passos sem sair do lugar - superação imaginária da morte pela multiplicação infinita das fotografias, borramento inútil da linha que divide $\Phi$. Mas Barthes tem tudo planejado. Seu monumento a Henriette é o livro, não a foto. Se fosse divulgada, seria multiplicada ao infinito - e essas inumeráveis partículas em que a mãe se dissolveria, negligenciadas, acabariam por erodir o livro-monumento cuidadosamente cinzelado.

\section{Referências}

AGAMBEN, Giorgio. The Coming Community. Minneapolis: University of Minnesota Press, 2007. 
AZEVEDO, Paulo César; LISSOVSKY, Mauricio. Escravos brasileiros do século XIX na Fotografia de Christiano Jr. São Paulo: Ex-Libris, 1988.

BARTHES, Roland. O Óbvio e o obtuso. Lisboa: Edições 70, 1984.

BARTHES, Roland. A Câmara Clara. Lisboa: Edições 70, 1989.

BAZIN, André. "Ontologia da imagem fotográfica". In: BAZIN, André. O Cinema. São Paulo: Brasiliense, 1991. p. 19-26.

BENVENISTE, Émile. Problèmes de linguistique générale. Paris: Gallimard, 1966.

CADAVA, Eduardo; CORTÉS-ROCCA, Paola. "Notes on Love and Photography". October, [s. l.], v. 116, Spring, p. 3-34, 2006. https://doi.org/10.1162/octo.2006.116.1.3.

DELEUZE, Gilles. Cinema I: A Imagem-movimento. São Paulo: Brasiliense: 1985.

DERRIDA, Jacques. "The Deaths of Roland Barthes". In: DERRIDA, J. The Works of Mourning. Chicago: University of Chicago Press, 2001. p. 31-68.

FOUCAULT, Michel. Nietzsche, Freud e Marx: Theatrum Philosoficum. Porto: Anagrama, 1980.

FOUCAULT, Michel. História da Sexualidade I: A Vontade de saber. Rio de Janeiro; Graal, 1982.

FRADE, Pedro Miguel. Figuras do Espanto: a fotografia antes da sua cultura. Porto: Edições Asa, 1992.

GAFFIOT, Félix. Dictionaire Illustré Latin-Français Paris: Hachette, 1934.

HUSSERL, Edmund. A Ideia da fenomenologia. Lisboa: Edições 70, 1990.

LÉVINAS, Emmanuel. La realidad y su sombra. Madrid: Editorial Trotta, 2001.

LISSOVSKY, Mauricio; BLANK, Thaís. "Catástrofe do sentido e urgência da montagem: o Brasil em 3 fotogramas alemães dos anos 1930". Devires, [s. l.], v. 7. n. 1, 2010.

LISSOVSKY, Mauricio. Pausas do Destino: teoria, arte e história da fotografia. Rio de Janeiro: Mauad X, 2014.

\section{Mauricio Lissovsky}

Doutor em Comunicação pela Universidade Federal do Rio de Janeiro, RJ, Brasil, professor do Programa de Pós-Graduação em Comunicação da Universidade Federal do Rio de Janeiro (UFRJ), Rio de Janeiro, RJ, Brasil.

\section{Endereço para correspondência}

Mauricio Lissovsky

Universidade Federal do Rio de Janeiro

Escola de Comunicação

Av. Pasteur 250 - fundos, sala 106

Botafogo, 22290-240

Rio de Janeiro, RJ, Brasil 